\title{
Isozyme analysis of the reported origin of a new hybrid orchid species, Epipactis youngiana (Young's helleborine), in the British Isles
}

\author{
STEPHEN A. HARRIS $† \&$ RICHARD J. ABBOTT*† \\ $\dagger$ School of Biological \& Medical Sciences, Sir Harold Mitchell Building, University of St Andrews, St Andrews, Fife \\ KY16 9TH, U.K. and $\ddagger$ Department of Plant Sciences, University of Oxford, South Parks Road, Oxford OX1 3RB, U.K.
}

\begin{abstract}
A survey of isozyme variation in what has been recorded as a new hybrid orchid species in the British Isles, Epipactis youngiana (Young's helleborine), and its putative parent species, has cast doubt on its supposed origins, i.e. stabilization of a hybrid product via autogamy after hybridization between $E$. helleborine $\times E$. leptochila or $E$. helleborine $\times E$. phyllanthes. Contrary to expectation, E. youngiana was found to contain a high level of genetic diversity and a genotypic structure indicative of outcrossing. Moreover, at a Glasgow site it appears to be interbreeding with two of its putative parents, E. helleborine and E. leptochila, to form part of a hybrid swarm. From the isozyme data, it is possible to dismiss the idea that $E$. phyllanthes may have acted as a parent of $E$. youngiana; however, it cannot be ruled out that the 'new species' is merely a variant form of $E$. helleborine or an introduction rather than a product of hybridization.
\end{abstract}

Keywords: British flora, Epipactis, hybrid, isozyme variation, orchid, speciation.

\section{Introduction}

The investigation of a new species soon after its origin can provide important information on mechanisms of speciation. For example much has been learned about the process of polyploid speciation from studies of several new plant polyploid species (Soltis \& Soltis, 1993). In addition to being the first step in allopolyploid speciation, interspecific hybridization can result in the origin of a plant species at the homoploid level (Grant, 1981), although the number of known examples of this remains very small (Gallez \& Gottlieb, 1982; Rieseberg, et al., 1990; Arnold, 1993). Where this process has been investigated in detail, reproductive isolation of the hybrid species is considered to result from recombination of chromosome differences between the parents. Alternatively, reproductive isolation in a sexually fertile hybrid could be achieved by autogamy (selfing).

Richards \& Porter (1982) recently described a new orchid species, Epipactis youngiana Richards \& Porter, growing on zinc- and lead-rich sites in Northumberland, England. They suggested that the species had not occurred on the Northumbrian sites for much more than 50 years, and from its

${ }^{*}$ Correspondence. E-mail: rja@st-andrews.ac.uk morphology speculated that it may have arisen through hybridization, followed by stabilization via autogamy, between E. helleborine (L.) Crantz and an autogamous Epipactis species such as E. dunensis ( $\mathrm{T}$. \& T.A. Stephenson) Godfrey or E. leptochila Godfrey. However, Stace (1991) in his Flora of the British Isles proposed that E. youngiana might be a hybrid derivative of $E$. helleborine and $E$. phyllanthes. Two hybrid origins have therefore been proposed for $E$. youngiana: $E$. helleborine $\times E$. leptochila (or a close relative) and $E$. helleborine $\times E$. phyllanthes.

Epipactis youngiana was recorded in Scotland, in the Glasgow area, in 1985, where it grew on coal slag heaps (bings) along with $E$. helleborine and $E$. leptochila var. dunensis Stephenson \& Stephenson. Dickson (1991) pointed out that E. phyllanthes was not present at these sites or elsewhere in Scotland, which ruled out a local origin of $E$. youngiana with E. phyllanthes acting as one of its parents.

To shed further light on the proposed hybrid origin of E. youngiana and the possibility that separate origins of the species may have occurred in England and Scotland, a survey was conducted of isozyme variation within population samples of $E$. youngiana, $E$. helleborine and $E$. leptochila from Glasgow and Northumberland, and also E. phyllanthes from Northumberland. At the outset of this 
study the following results were expected based on what was known or had been proposed for these taxa. First, high levels of genetic (allozyme) diversity should be present in populations of the allogamous (outcrossing) species E. helleborine in contrast to low levels of diversity present in populations of the supposedly autogamous (selfing) species E. leptochila and E. phyllanthes (Hamrick \& Godt, 1989). Secondly, observed genotypic frequencies should be at Hardy-Weinberg equilibrium in $E$. helleborine populations, assuming random mating and absence of population substructure, whereas a marked deficiency of heterozygotes should be evident in populations of E. leptochila and E. phyllanthes because of predominant self-fertilization. Thirdly, if E. youngiana originated in the ways proposed by either Richards \& Porter (1982) or Stace (1991), i.e. as a segregant of hybridization between $E$. helleborine and E. leptochila or E. phyllanthes, stabilized through autogamy, it would be expected that its populations should contain extremely low levels of genetic diversity and most probably be composed of plants that share the same homozygous genotype over all loci examined. This should be so unless a large number of segregating genotypes was fixed by autogamy during the course of the hybrid origin of $E$. youngiana with the species retaining a genetic constitution distinct from either parent. This is unlikely, and would not alter the expectation that each $E$. youngiana plant should possess a highly homozygous genotype because of autogamy. Additional findings in regard to separate origins of Glasgow and Northumberland $E$. youngiana would depend on the distribution of allozyme variation between the putative parent species over the two sites.

\section{Materials and methods}

Plants of E. youngiana and its putative parent species were sampled from the locations listed in
Table 1. Floral bracts were harvested in the field, placed in snap-top plastic bags and either put in a cool place or packed in ice before returning to the laboratory. In the laboratory, material was either processed immediately or stored at $4^{\circ} \mathrm{C}$ and processed within $48 \mathrm{~h}$ of collection. Electrophoresis was used to separate isozymes in crude protein extracts obtained from the floral bracts by standard techniques (Wendel \& Weeden, 1989).

Nine enzyme systems were resolved: aspartate aminotransferase (AAT, EC 2.6.1.1); $\alpha$-esterase $(\alpha \mathrm{EST}, \mathrm{EC} 3.1 .1 .-) ; \beta$-esterase $(\beta \mathrm{EST}$, EC 3.1.1.-); glyceraldehyde-3-phosphate dehydrogenase (G-3-PD, EC 1.2.1.9); isocitrate dehydrogenase (IDH, EC 1.1.1.42); 6-phosphogluconate dehydrogenase (6-PGD, EC 1.1.1.44); phosphoglucoisomerase (PGI, EC 5.3.1.9); phosphoglucomutase (PGM, EC 5.4.2.2); superoxide dismutase (SOD, EC 1.15.1.1). Where two or more isozymes for a given enzyme were resolved on a gel and were considered to be the gene products of different loci, the locus coding for the most anodally migrating protein was designated 1 , the next 2 , etc. Similarly, at each polymorphic locus the allele encoding the most anodally migrating isozyme was designated $a$, the next $b$, etc. The genetics for each of the isozyme loci identified were inferred from the known enzyme subunit structure (Weeden \& Wendel, 1989) and the assumption that all of the material was diploid.

A full description of the electrophoretic and staining procedures used and the isozyme banding patterns resolved for each enzyme system and their genetic interpretation may be obtained from S. A. Harris on request.

\section{Results and discussion}

Seventeen isozyme loci were identified over the nine enzyme systems. Of these, 14 (82.3 per cent) were polymorphic across the species analysed (Table 2).

Table 1 Locations and sizes of Epipactis samples surveyed

\begin{tabular}{llc}
\hline Location & Taxon & Number of plants \\
\hline Northumberland & & \\
Settling Stones (SS) site 1 & E. youngiana & 29 \\
SS sites 1, 2, 3 and Warden & E. helleborine & 14 \\
Beltingham and Warden & E. leptochila & 20 \\
SS sites 1, 2, 3 & E. phyllanthes & 16 \\
Glasgow & & \\
Bardykes Bing (BB) & E. youngiana & 76 \\
BB and Bothwell Priory & E. helleborine & 6 \\
BB and Bothwell Priory & E. leptochila & 17 \\
\hline
\end{tabular}


Table 2 Allele frequencies at polymorphic loci for Epipactis species sampled from Northumberland $(\mathrm{N})$ and Glasgow $(\mathrm{G})$ areas. Numbers in brackets are sample sizes

\begin{tabular}{|c|c|c|c|c|c|c|c|}
\hline \multirow[b]{2}{*}{ Locus } & \multicolumn{2}{|c|}{ E. youngiana } & \multicolumn{2}{|c|}{ E. helleborine } & \multicolumn{2}{|c|}{ E. leptochila } & \multirow{2}{*}{$\frac{\text { E. phyllanthes }}{\mathrm{N}}$} \\
\hline & $\mathrm{N}$ & G & $\mathrm{N}$ & G & $\mathrm{N}$ & G & \\
\hline $\begin{array}{r}\text { Aat-1a } \\
b \\
c\end{array}$ & $\begin{array}{l}0.91 \\
0.07 \\
0.02 \\
(29)\end{array}$ & $\begin{array}{l}0.83 \\
0.13 \\
0.04 \\
(76)\end{array}$ & $\begin{array}{l}0.75 \\
0.25 \\
- \\
(14)\end{array}$ & $\frac{1.00}{-}$ & $\frac{1.00}{-}$ & $\begin{array}{l}0.79 \\
0.09 \\
0.12 \\
(17)\end{array}$ & $\frac{1.00}{-}$ \\
\hline $\begin{array}{r}\text { Aat }-2 a \\
-\end{array}$ & $\frac{1.00}{(29)}$ & $\frac{1.00}{(73)}$ & $\frac{1.00}{(14)}$ & $\frac{1.00}{(5)}$ & $\frac{1.00}{(20)}$ & $\frac{1.00}{(17)}$ & $\begin{array}{l}-\overline{1.00} \\
(16)\end{array}$ \\
\hline$\stackrel{A a t-3 a}{-}$ & $\frac{1.00}{(29)}$ & $\frac{1.00}{(73)}$ & $\frac{1.00}{(14)}$ & $\frac{1.00}{(6)}$ & $\frac{1.00}{(20)}$ & $\frac{1.00}{(17)}$ & $\begin{array}{l}-\overline{1.00} \\
(16)\end{array}$ \\
\hline$\stackrel{\text { Aat }-4 a}{-}$ & $\begin{array}{l}- \\
1.00 \\
(29)\end{array}$ & $\begin{array}{l}- \\
1.00 \\
(75)\end{array}$ & $\begin{array}{l}- \\
1.00 \\
(14)\end{array}$ & $\begin{array}{l}- \\
1.00 \\
(6)\end{array}$ & $\begin{array}{c}- \\
1.00 \\
(20)\end{array}$ & $\begin{array}{l}- \\
1.00 \\
(17)\end{array}$ & $\frac{1.00}{-}$ \\
\hline $\begin{array}{r}I d h-1 a \\
b\end{array}$ & $\begin{array}{c}1.00 \\
\frac{-}{(29)}\end{array}$ & $\begin{array}{l}0.79 \\
0.21 \\
(70)\end{array}$ & $\begin{array}{l}0.93 \\
0.07 \\
(14)\end{array}$ & $\frac{1.00}{(5)}$ & $\frac{1.00}{(20)}$ & $\begin{array}{l}0.81 \\
0.19 \\
(16)\end{array}$ & $\frac{1.00}{(16)}$ \\
\hline$\stackrel{I d h-2 a}{-}$ & $\begin{array}{l}- \\
1.00 \\
(29)\end{array}$ & $\begin{array}{l}-- \\
1.00 \\
(75)\end{array}$ & $\begin{array}{l}-\overline{1.00} \\
(14)\end{array}$ & $\begin{array}{l}- \\
1.00 \\
(6)\end{array}$ & $\begin{array}{l}- \\
1.00 \\
(20)\end{array}$ & $\begin{array}{l}- \\
1.00 \\
(17)\end{array}$ & $\frac{1.00}{-}$ \\
\hline $\begin{array}{r}P g i-1 a \\
b\end{array}$ & $\begin{array}{l}-- \\
1.00 \\
(29)\end{array}$ & $\begin{array}{l}-\overline{1.00} \\
(76)\end{array}$ & $\begin{array}{l}- \\
1.00 \\
(14)\end{array}$ & $\begin{array}{l}- \\
1.00 \\
(6)\end{array}$ & $\begin{array}{l}-\overline{1.00} \\
(20)\end{array}$ & $\begin{array}{l}-\overline{1.00} \\
(17)\end{array}$ & $\frac{1.00}{(16)}$ \\
\hline $\begin{array}{r}P g i-2 a \\
b \\
c\end{array}$ & $\begin{array}{l}0.43 \\
0.16 \\
0.41 \\
(29)\end{array}$ & $\begin{array}{l}0.33 \\
0.03 \\
0.64 \\
(75)\end{array}$ & $\begin{array}{l}0.61 \\
0.07 \\
0.32 \\
(14)\end{array}$ & $\begin{array}{c}0.50 \\
-\overline{-} \\
0.50 \\
(5)\end{array}$ & $\begin{array}{c}- \\
\overline{1.00} \\
(20)\end{array}$ & $\begin{array}{l}0.41 \\
0.09 \\
0.50 \\
(17)\end{array}$ & $\frac{\overline{1.00}}{-}$ \\
\hline $\begin{array}{r}P g m-1 a \\
b \\
c\end{array}$ & $\begin{array}{c}- \\
0.59 \\
0.41 \\
(29)\end{array}$ & $\begin{array}{l}-\overline{76} \\
0.24 \\
(70)\end{array}$ & $\begin{array}{l}- \\
0.50 \\
0.50 \\
(14)\end{array}$ & $\begin{array}{c}- \\
0.80 \\
0.20 \\
(5)\end{array}$ & $\begin{array}{c}- \\
- \\
1.00 \\
(20)\end{array}$ & $\begin{array}{l}-\overline{0.70} \\
0.30 \\
(15)\end{array}$ & $\begin{array}{c}1.00 \\
- \\
- \\
(16)\end{array}$ \\
\hline $\begin{array}{r}\text { Sod-1a } \\
b\end{array}$ & $\begin{array}{l}0.89 \\
0.11 \\
(27)\end{array}$ & $\begin{array}{l}0.91 \\
0.09 \\
(76)\end{array}$ & $\frac{1.00}{(6)}$ & $\begin{array}{c}0.75 \\
0.25 \\
(6)\end{array}$ & $\frac{1.00}{(20)}$ & $\begin{array}{l}0.82 \\
0.18 \\
(17)\end{array}$ & $\begin{array}{l}0.73 \\
0.27 \\
(16)\end{array}$ \\
\hline $\begin{array}{r}\beta E s t-1 a \\
b\end{array}$ & $\frac{1.00}{(29)}$ & $\begin{array}{l}0.90 \\
0.10 \\
(67)\end{array}$ & $\frac{1.00}{(14)}$ & $\begin{array}{l}0.80 \\
0.20 \\
(5)\end{array}$ & $\frac{1.00}{(20)}$ & $\frac{1.00}{(15)}$ & $\frac{1.00}{-}$ \\
\hline $\begin{array}{r}\beta E s t-2 a \\
b\end{array}$ & $\begin{array}{l}0.08 \\
0.92 \\
(26)\end{array}$ & $\begin{array}{l}0.46 \\
0.54 \\
(56)\end{array}$ & $\begin{array}{l}- \\
1.00 \\
(12)\end{array}$ & $\begin{array}{l}0.50 \\
0.50 \\
(5)\end{array}$ & $\begin{array}{l}-\overline{1.00} \\
(3)\end{array}$ & $\begin{array}{c}0.39 \\
0.61 \\
(9)\end{array}$ & $\begin{array}{l}-\overline{1.00} \\
(16)\end{array}$ \\
\hline $\begin{array}{r}\beta E s t-3 a \\
b\end{array}$ & $\begin{array}{l}0.85 \\
0.15 \\
(26)\end{array}$ & $\begin{array}{l}0.42 \\
0.58 \\
(51)\end{array}$ & $\frac{1.00}{(12)}$ & $\begin{array}{l}0.60 \\
0.40 \\
(5)\end{array}$ & $\frac{1.00}{(3)}$ & $\begin{array}{c}0.50 \\
0.50 \\
(8)\end{array}$ & $\frac{1.00}{(16)}$ \\
\hline $\begin{array}{r}\alpha E s t-1 a \\
b\end{array}$ & $\frac{1.00}{(30)}$ & $\begin{array}{l}1.00 \\
- \\
(72)\end{array}$ & $\frac{1.00}{(14)}$ & $\frac{1.00}{(6)}$ & $\frac{1.00}{(20)}$ & $\begin{array}{l}0.94 \\
0.06 \\
(16)\end{array}$ & $\frac{1.00}{(16)}$ \\
\hline
\end{tabular}

(C) The Genetical Society of Great Britain, Heredity, 79, 402-407. 
Epipactis phyllanthes was readily distinguished from $E$. helleborine, E. leptochila and $E$. youngiana on the bases of the presence/absence of four loci and two alleles. Two loci, Aat-2 and Aat-3, were absent from $E$. phyllanthes but present in the other three species, whereas another two loci, Aat-4 and Idh-2, were present in $E$. phyllanthes but absent from the other taxa. Two alleles, Pgi-1a and Pgm-1a, were fixed in $E$. phyllanthes but were not present in the other taxa. These and additional differences of allele frequencies over loci were reflected in the low values of Nei's genetic identity (Nei, 1972) calculated for $E$. phyllanthes and the other taxa (Table 3 ). In contrast, high levels of genetic identity were evident between E. helleborine, E. leptochila and E. youngiana.

The absence from $E$. youngiana of loci and alleles that are diagnostic of $E$. phyllanthes is strong evidence that $E$. phyllanthes is unlikely to have acted as a parent of $E$. youngiana. That said, if, as proposed by Richards \& Porter (1982), E. youngiana is a hybrid derivative stabilized by autogamy, it is feasible that it might contain only a small portion of the genetic material of one of its parents (e.g. $E$. phyllanthes) and be largely composed of genes inherited from its other parent. However, as pointed out below, it appears that $E$. youngiana engages in outcrossing rather than autogamy at its Northumberland and Glasgow sites, in which case the diagnostic alleles of $E$. phyllanthes should have been retained in $E$. youngiana if $E$. phyllanthes had been a parent.

Because of the relatively large numbers of individuals surveyed in the Glasgow and Northumberland populations of $E$. youngiana, it was possible to analyse the genetic diversity within and between these two populations in some detail. For the other three species fewer individuals (pooled over several sites) were surveyed and only the proportion of polymorphic loci $(P)$ and mean number of alleles per locus $(A)$ were calculated. In Northumberland, $E$. helleborine was found to contain a greater amount of genetic diversity than either E. leptochila or E. phyllanthes as reflected in its higher values of $P$ and $A$ (Table 4). This result was expected given that $E$. helleborine is allogamous, whereas the other two species are believed to be autogamous (Richards \& Porter, 1982). Material of E. leptochila sampled from Northumberland was monomorphic for a single allele and consequently homozygous at each locus examined, and $E$. phyllanthes also exhibited a high level of homozygosity, being polymorphic at only one locus (Sod-1). In contrast to expectation, the Northumberland population of $E$. youngiana contained a high level of genetic diversity with $P$ and $A$-values greater than those calculated for $E$. helleborine. Moreover, observed genotype frequencies in this population were not significantly different from those expected at Hardy-Weinberg equilibrium at four of the six polymorphic loci [nonsignificant $\chi^{2}$ values and low fixation indices $(F)$, Table 5]. This would suggest that random mating is occurring in this population of $E$. youngiana rather than predominant self-fertilization.

In Glasgow, similar amounts of genetic diversity were present in $E$. helleborine and $E$. youngiana as were found in the Northumberland samples. However, Glasgow E. leptochila contained high levels of allelic diversity and observed heterozygosity, in contrast to what was expected for this reportedly autogamous species. Examination of observed heterozygote frequencies in the Glasgow E. youngiana population showed again that these were not significantly different from those expected at HardyWeinberg equilibrium at the majority of polymorphic loci (Table 5), indicating once more that this species engages in outcrossing rather than predominant self-fertilization.

The amount of total genetic diversity in E. youngiana and the manner in which it is partitioned within and between the Northumberland and Glasgow populations was analysed by calculating Nei's indices

Table 3 Nei's index of genetic identity between samples of Epipactis species from Northumberland (N) and Glasgow (G)

\begin{tabular}{|c|c|c|c|c|c|c|c|}
\hline & & \multirow{2}{*}{$\frac{\text { E. phyllanthes }}{\mathrm{N}}$} & \multicolumn{2}{|c|}{ E. leptochila } & \multicolumn{2}{|c|}{ E. helleborine } & \multirow{2}{*}{$\frac{\text { E. youngiana }}{\mathrm{G}}$} \\
\hline & & & G & $\mathrm{N}$ & G & $\mathrm{N}$ & \\
\hline E. youngiana & $\begin{array}{l}N \\
G\end{array}$ & $\begin{array}{l}0.601 \\
0.533\end{array}$ & $\begin{array}{l}0.918 \\
0.996\end{array}$ & $\begin{array}{l}0.960 \\
0.918\end{array}$ & $\begin{array}{l}0.981 \\
0.989\end{array}$ & $\begin{array}{l}0.993 \\
0.950\end{array}$ & 0.969 \\
\hline E. helleborine & $\begin{array}{l}N \\
G\end{array}$ & $\begin{array}{l}0.591 \\
0.549\end{array}$ & $\begin{array}{l}0.964 \\
0.989\end{array}$ & $\begin{array}{l}0.956 \\
0.914\end{array}$ & 0.954 & & \\
\hline E. leptochila & $\begin{array}{l}N \\
G\end{array}$ & $\begin{array}{l}0.549 \\
0.548\end{array}$ & 0.926 & & & & \\
\hline
\end{tabular}


Table 4 Summary of allozyme variation for 15 loci within Epipactis species sampled from Northumberland $(\mathrm{N})$ and Glasgow (G): proportion of polymorphic loci $(P)$, mean number of alleles per locus $(A)$, mean observed heterozygosity $\left(H_{\mathrm{o}}\right)$, mean expected heterozygosity $\left(H_{\mathrm{e}}\right)$ and mean fixation index $(F)$

\begin{tabular}{lcccccc}
\hline Species & & $P$ & $A$ & $H_{\mathrm{o}}$ & $H_{\mathrm{e}}$ & $F$ \\
\hline E. youngiana & $(\mathrm{N})$ & 0.40 & 1.53 & 0.11 & 0.11 & 0.18 \\
& $(\mathrm{G})$ & 0.53 & 1.67 & 0.17 & 0.18 & 0.12 \\
E. helleborine & $(\mathrm{N})$ & 0.27 & 1.33 & & & \\
& $(\mathrm{G})$ & 0.40 & 1.40 & & & \\
E. leptochila & $(\mathrm{N})$ & 0.00 & 1.00 & & & \\
& $(\mathrm{G})$ & 0.53 & 1.67 & & & \\
E. phyllanthes & $(\mathrm{N})$ & 0.07 & 1.07 & & & \\
\hline
\end{tabular}

of gene diversity (Nei, 1973). The mean level of total gene diversity $\left(H_{\mathrm{T}}\right)$ estimated over all 15 loci examined in this species was 0.170 (Table 6). Most of this was attributable to diversity within populations $\left(H_{S}=0.150\right)$ rather than between populations $\left(D_{\mathrm{ST}}=0.020\right)$. The mean proportion of total gene diversity attributable to between-population diversity assessed over polymorphic loci $\left(G_{\mathrm{ST}}\right.$, which is equivalent to Wright's $F_{\text {ST }}$, Hartl \& Clarke, 1989) was equal to 9.3 per cent, indicating that the two populations of $E$. youngiana were genetically very similar to each other.

These results raise a number of questions regarding the status and proposed origin of E. youngiana in Northumberland and the Glasgow area. The high level of genetic diversity that was recorded in both populations of E. youngiana and the fact that geno-

Table 5 Observed heterozygosity $\left(H_{\mathrm{o}}\right)$ and Wright's fixation index $\left(F_{\mathrm{o}}\right)$ at polymorphic loci in populations of Epipactis youngiana from Settling Stones (Northumberland) and Bardykes Bing (Glasgow)

\begin{tabular}{|c|c|c|c|c|}
\hline \multirow[b]{2}{*}{ Locus } & \multicolumn{2}{|c|}{ Settling Stones } & \multicolumn{2}{|c|}{ Bardykes Bing } \\
\hline & $H_{0}$ & $F_{\mathrm{o}}$ & $H_{0}$ & $F_{\circ}$ \\
\hline Aat-1 & 0.17 & -0.09 & 0.26 & 0.20 \\
\hline$I d h-1$ & 0.00 & - & 0.33 & 0.00 \\
\hline Pgi-2 & 0.62 & -0.28 & 0.39 & 0.19 \\
\hline Pgm-1 & 0.41 & 0.15 & 0.30 & 0.17 \\
\hline Sod-1 & 0.22 & -0.12 & 0.17 & -0.09 \\
\hline BEst-1 & 0.00 & - & $0.04^{* * * *}$ & 0.74 \\
\hline$\beta$ Est -2 & $0.00^{* * * *}$ & 1.00 & 0.46 & 0.07 \\
\hline$\beta E s t-3$ & $0.15^{*}$ & 0.41 & $0.65^{*}$ & -0.33 \\
\hline
\end{tabular}

Observed genotype frequencies significantly different from expectation under Hardy-Weinberg equilibrium when $* P<0.05$ and $* * * P<0.001$.
Table 6 Measures of genetic diversity in Epipactis youngiana at eight polymorphic loci

\begin{tabular}{lccccc}
\hline Locus & $H_{\mathrm{o}}$ & $H_{\mathrm{S}}$ & $H_{\mathrm{T}}$ & $D_{\mathrm{ST}}$ & $G_{\mathrm{ST}}$ \\
\hline Aat-1 & 0.218 & 0.225 & 0.228 & 0.002 & 0.007 \\
Idh-1 & 0.164 & 0.164 & 0.186 & 0.022 & 0.116 \\
Pgi-2 & 0.504 & 0.484 & 0.570 & 0.086 & 0.151 \\
Pgm-1 & 0.357 & 0.422 & 0.439 & 0.016 & 0.037 \\
Sod-1 & 0.196 & 0.177 & 0.177 & 0.000 & 0.000 \\
BEst-1 & 0.022 & 0.087 & 0.092 & 0.004 & 0.048 \\
BEst-2 & 0.232 & 0.319 & 0.395 & 0.075 & 0.190 \\
BEst-3 & 0.400 & 0.374 & 0.464 & 0.090 & 0.193 \\
Mean (i) $\dagger$ & 0.262 & 0.282 & 0.319 & 0.037 & 0.093 \\
Mean (ii)* & 0.140 & 0.150 & 0.170 & 0.020 & \\
\hline
\end{tabular}

$\uparrow$ Means for polymorphic loci only.

*Means for all loci.

type frequencies were at Hardy-Weinberg equilibrium do not support the proposal that this species is an autogamous hybrid derivative of $E$. helleborine $\times E$. leptochila or E. phyllanthes. Richards \& Porter (1982) described E. youngiana as possessing flowers that 'resemble those of $E$. helleborine, being rather large, patent and open, but share with the self-pollinating species E. leptochila ... and E. phyllanthes pollinia which usually disintegrate as the flower opens, and an evanescent viscidium'. They futher emphasized that in 'self-pollinating (autogamous) species, the viscidium withers as the flower opens, and the pollinia disintegrate on to the stigma surface', which should enable self-fertilization to follow rapidly. They concluded that, although in floral features $E$. youngiana closely resembles $E$. helleborine, it was clearly autogamous. The results of our isozyme analysis are at variance with this conclusion, and would suggest that a more detailed analysis of the breeding system of $E$. youngiana (and $E$. leptochila) is now required. Richards \& Porter (1982) pointed out that visits to the nectar-containing hypochile in E. youngiana (and E. leptochila) by small insects are common, and 'it is likely that some casual cross-pollination of loose tetrads will occur'. It is feasible that these insects are more effective pollinators than thought hitherto, causing mating to occur at random in E. youngiana populations.

If $E$. youngiana engages in outcrossing, the question is raised as to how this species could be derived from hybridization and yet be reproductively isolated from its putative parents. Although there is no published chromosome number for E. youngiana, the isozyme analysis has shown that it behaves as a diploid and consequently is not isolated from its putative parents through polyploidy. Reproductive

(C) The Genetical Society of Great Britain, Heredity, 79, 402-407. 
isolation may be maintained at certain sites by differences in flowering times; Richards \& Porter (1982) reported that $E$. youngiana tends to flower some 2 weeks earlier than $E$. helleborine at Northumberland sites, and this may reduce interspecific crossing to very low levels.

Whereas at Northumberland sites plants could be assigned to taxa with confidence, far greater difficulty was encountered in the Glasgow area. At Bardykes Bing, Glasgow, it was particularly difficult to separate E. youngiana from E. leptochila based on morphology. The close resemblance between these two taxa at this site was confirmed by their very high genetic identity $(I=0.996$, Table 3$)$, which reflects the fact that both taxa had similar allele frequencies over a range of polymorphic loci. The high proportion of polymorphic loci $(P)$ and allelic diversity $(A)$ in Glasgow material of $E$. leptochila was unexpected, given the absence of polymorphism in Northumberland material of E. leptochila. When taken together, the field observations and results of the isozyme survey would suggest that whereas $E$. youngiana is reproductively isolated from $E$. leptochila in Northumberland, this is unlikely to be so at their Glasgow sites. In fact, $\chi^{2}$-tests of goodness of fit of observed to Hardy-Weinberg genotype frequencies in the Bardykes Bing population conducted on data pooled over E. youngiana, E. leptochila and E. helleborine showed that deviations of observed from expected were not significant at four of the eight polymorphic loci examined ( $\alpha$ EST-1 not included in the analysis). This would indicate that random mating may be occurring across taxonomic boundaries in this population, which might therefore be best considered as a hybrid swarm. This, in turn, casts doubt on whether E. youngiana exists as a circumscribed taxon at the Glasgow site, and suggests that what has been classified as $E$. youngiana at this site may be unstabilized hybrid material of $E$. helleborine and E. leptochila.

The results reported here make it clear that much more investigation needs to be undertaken on the biology of $E$. youngiana and its close relatives at its Northumberland and Glasgow sites before we are clear about the status of this taxon and its origin. This should involve detailed morphometric analysis of the relevant taxa, assessment of their breeding systems in the wild, measurement of amounts of interspecific crossing and the nature of isolating barriers. Until this work is carried out, we cannot be sure of whether we are dealing with a new stabilized hybrid taxon. The present data do not rule out the possibility that $E$. youngiana is a variant form of $E$. helleborine or an introduction from abroad. Both of these possibilities require further investigation.

\section{Acknowledgements}

We are grateful to the Scottish Natural Heritage for funding the study (SNH Contract no. SS/F2B/459 A), to Keith Watson (Glasgow Museum) for collecting Epipactis bracts from the Glasgow populations and transporting them to St Andrews, and to John Richards (University of Newcastle upon Tyne) for his help in identifying and collecting material of Epipactis from Northumberland.

\section{References}

ARNOLD, M. L. 1993. Iris nelsonii (Iridaceae): origin and genetic composition of a homoploid hybrid species. Am. J. Bot, 80, 577-583.

Dickson, J. H. 1991. Wild Plants of Glasgow. Aberdeen University Press, Aberdeen.

GALLEZ, G. P. AND GOTTLIEB, L. D. 1982. Genetic evidence for the hybrid origin of the diploid plant Stephanomeria diegensis. Evolution, 36, 1158-1167.

grant, v. 1981. Plant Speciation. Columbia University Press, New York.

HAMRICK, J. L. AND GODT, M. J. (1989) Allozyme diversity in plant species. In: Brown, A. H., Clegg, M. T., Kahler, A. L. and Weir, B. S. (eds) Population Genetics and Germplasm Resources in Crop Improvement, pp. 44-64. Sinauer, Sunderland, MA.

HARTL, D. L. AND ClARK, A. G. 1989. Principles of Population Genetics, 2nd edn. Sinauer, Sunderland, MA.

NEl, M. 1972. Genetic distance between populations. Am. Nat., 106, 283-292.

NEl, M. 1973. Analysis of gene diversity in subdivided populations. Proc. Natl. Acad. Sci. U.S.A., 70, 3321-3323.

RICHARDS, A. J. AND PORTER, A. F. 1982. On the identity of a Northumberland Epipactis. Watsonia, 14, 121-128.

RiESEBERG, L. H., CARTER, R. AND zONA, s. 1990. Molecular tests of the hypothesised hybrid origin of two diploid Helianthus species. Evolution, 44, 1498-1511.

solT1S, D. E. AND solT1S, P. s. 1993. Molecular data and the dynamic nature of polyploidy. Crit. Rev. Plant Sci, 12, 243-273.

STACE, C. A. 1991. New Flora of the British Isles. Cambridge University Press, Cambridge.

WEEDEN, N. F. AND WENDEL, J. F. 1989. Genetics of plant isozymes. In: Soltis, D. E. and Soltis P. S. (eds) Isozymes in Plant Biology, pp. 46-72. Chapman \& Hall, London.

WENDEL, J. F. AND WEEDEN, N. F. 1989. Visualization and interpretation of plant isozymes. In: Soltis, D. E. and Soltis, P. S. (eds) Isozymes in Plant Biology, pp. 5-45. Chapman \& Hall, London. 